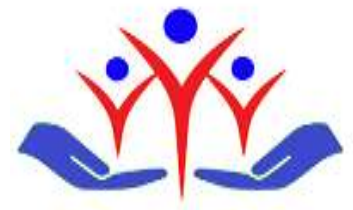

\title{
Role of mother education level in delivery method preference
}

\author{
Doğum yöntemi tercihinde anne eğitim düzeyinin rolü
}

\section{Cuney Ardic ${ }^{\mathrm{a}}$}

${ }^{a}$ Recep Tayyip Erdogan University, School of Medicine, Department of Family Medicine, Rize, Turkey

\begin{abstract}
Introduction: Cesarean section rate (CS) has increased to $15.5 \%$ in 2012 while it was $12 \%$ in 2000s, in general. Information during these follow-ups is very important for pregnant women to decide on delivery method. Another aspect that affects women's delivery method is the education level. The objective of this study is to investigate the effect of education level on delivery method for pregnant women.

Method: This descriptive study was carried out by the participation of 500 pregnant women who were regularly followed in Family Physician Polyclinic in Rize between January 2016 and December 2017. Each pregnant woman was followed up in Family Health Center at least 4 times during pregnancy. Methods of delivery of pregnants participating in the study were determined, and the factors affecting them were investigated with appropriate statistical methods.

Results: Of 500 pregnant women included in the study, 254 (50.8\%) women were between the ages of 20-35 and the majority (n=282; 56.4\%) were primary and secondary school graduates. $52(10.4 \%)$ of the mothers were smoking while $104(20.8 \%)$ mothers were working at any job. The mean age of the mothers participating to study is $28.8 \pm 9.8$. No correlation was found between the delivery method and age groups. ( $\mathrm{p}=0.651$ ) Patients were divided into three groups as primary and secondary school graduates, high school graduates and university graduates according to the education level. University and higher education group was significantly choosing cesarean section more than primary school graduates groups. ( $\mathrm{p}=0.021$ )

Conclusion: In this study carried out in Turkey, where cesarean section is performed in the world at most, we have figured out that there is a relation between high education level and socio-economic status of pregnant women and cesarean delivery preference.

Keywords: Caesarean Section, mother, pregnancy
\end{abstract}

\section{$\ddot{O} \mathbf{Z}$}

Giriş: Genel olarak, dünyada sezeryan oranı (CS) 2000 li yıllarda \% 12 iken 2012'de \% 15,5'e yükseldi. Gebe kadınların doğum yöntemine karar vermesinde izlemler sırasında yapılan bilgilendirmeler önem taşımaktadır. Kadınların doğum yöntemini etkileyen bir başka durum ise gebe kadınların eğitim durumudur. Bu çalışmanın amacı gebe kadınlarda eğitim düzeyinin doğum yöntemine etkisini araştırmaktır.

Yöntem: Tanımlayıcı tipteki bu araştırma Rize ilinde Aile Hekimliği polikliniğinde 2016 Ocak ayı ile 20017 Aralık ayları arasında düzenli takipleri yapılan 500 gebenin katılımı ile yapılmıştır. Her bir gebenin takibi gebeliği boyunca en az 4 kez Aile Sağlı Merkezinde yapılmıştır. Çalışmaya katılan gebelerin doğum yöntemleri belirlenerek buna etki eden faktörler uygun istatistiksel yöntemlerle araştırılmıştır.

Bulgular: Çalışmaya alınan 500 gebenin $254(\% 50,8)$ i 20-35 yaş aralığında olup çoğunluğu $(\mathrm{n}=282 ; \% 56,4)$ ilk-orta öğrenim mezunudur. Çalışmaya katılan annelerin $52(\% 10,4)$ si sigara kullanırken $104(\% 20,8)$ ü herhangi bir işte çalışmaktaydı. Çalışmaya katılan annelerin ortalama yaşı $28,8 \pm 9,8$ dir. Doğum yöntemi ile yaş grupları arasında bir ilişki saptanmamıştır. ( $\mathrm{p}=0,651)$ Eğitim durumlarına hastalar ilk ve orta öğretim,lise ve üniversite olmak üzere 3 gruba ayrıldı. Üniversite ve üstü mezun grup ilköğretim mezun gruba göre anlamlı derecede daha fazla sezeryanla doğum yöntemini seçmekteydi $(\mathrm{p}=0,021)$.

Sonuç: Dünyada sezeryanla doğumun en çok yapıldığı ülke olan Türkiye de yaptığımız çalışmada gebe eğitim düzeyinin yüksek olması ve sosyoekonomik durumun yüksek olmasını sezeryan doğum tercihi ile ilişkili bulduk.

Anahtar Kelimeler: Sezeryan, anne, gebelik
Submission: Jan 22, 2018
Acceptance: Mar 22, 2018
E-Mail: drcuneytardic@ hotmail.com

Correspondence: Cuneyt Ardic, MD

Recep Tayyip Erdogan University, School of Medicine, Department of Family Medicine, Rize, Turkey

www.fppc.com.tr 


\section{Introduction}

Cesarean section rate (CS) has increased to $15.5 \%$ in 2012 while it was $12 \%$ in 2000s, in general [1]. According to the data of The Organization for Economic Co-operation and Development (OECD) in 2016, Turkey ranks first in the world with 54.1\% cesarean rate [2]. CS rate is nearly ten times compared to the World Health Organization (WHO) recommendation. Pregnancy follow-up is carried out in Family Health Centers in Turkey for at least 4 times for each pregnant woman. Information during these follow-ups is very important for pregnant women to decide on delivery method. Another aspect that affects women's delivery method is the education level [3].

Cesarean delivery is defined as the birth of fetus, placenta and membranes thorough the incision on abdominal and uterus walls [4]. Some factors such as development of imaging techniques, prevalence of electronic fetal monitor, progress of gestational age, decrease of parity number, increase of forensic events in medical complications and malpractice cases and socioeconomic and demographic factors have also increased cesarean rates day by day [5]. Socioeconomic status of the pregnant woman, attitude of the physician, convenience factors, legal aspects, payment method, expectation and psychological status of women were found to be most important non-medical factors associated with delivery method [6].

In conclusion, women can decide on appropriate delivery method affected by all these factors; but sometimes they might give birth in a different manner than planned intentionally or unintentionally. The important point here is that pregnant women are informed by correct sources at adequate level, directed to appropriate delivery method and the delivery ends with healthy mother and baby. Our aim in this study is to investigate the effect of education level on delivery method.

\section{Methods}

\section{Study population}

Our study was carried out by the participation of 500 pregnant women who were regularly followed in Family Physician Polyclinic in Rize between January 2016 and December 2017. Each pregnant woman was followed up in Family Health Center at least 4 times during pregnancy. All pregnant women included in the study were also followed up at least once by the same family physicians during postpartum period.

Primiparous pregnant women were included in the study while those having elective cesarean indication, having multiple pregnancies, giving birth before 37 weeks, having chronic diseases and those who did not come for regular follow-up for any reason during pregnancy were excluded.

\section{Ethical procedure}

Ethics committee approval for this study was taken from the Ethics Committee of Recep Tayyip Erdogan University Faculty of Medicine with protocol number 2018/29. In addition, informed consent forms were obtained from the mothers in their pregnancy.

\section{Statistical analysis}

The SPSS version 20.0 statistical software package was used for the research data.. Evaluation of the data was conducted with descriptive statistical methods (average, median, standard deviation); furthermore, student T test was used to compare normal distribution variables whereas Mann-Whitney U test to compare non-normal distribution variables. Pearson's correlation was used to investigate the correlations between the variables. Statistical significance was defined at a level of $5 \%(\mathrm{p}<0.05)$.

\section{Results}

Sociodemographic attributes of the participants are shown in Table 1. Of the 500 pregnant women included in the study, 254 (50.8\%) women were between the ages of 20-35 and the majority $(\mathrm{n}=282 ; 56.4 \%)$ were primary and secondary school graduates. $52(10.4 \%)$ of the mothers were smoking while 104 (20.8\%) mothers were working at any job. Of the 500 participants in the study, $441(88.2 \%)$ women had follow-up at least 4 times in family health center during pregnancy.

Table 2 shows the relation between various factors and pregnant women having participated in the study. The mean age of the mothers participating to study is $28.8 \pm 9.8$. No correlation was found between the delivery method and age groups. $(\mathrm{p}=0.651)$ Patients were divided into three groups as primary and secondary school graduates, high school graduates and university graduates according to the education level. University and higher education group was significantly choosing cesarean section more than primary school graduates groups. $(\mathrm{p}=0.021)$

Families participating in the study were divided into 3 groups including those with monthly income of $500 €$ or less, with 500-1000 $€$ and more than $1000 €$. When delivery methods were analyzed depending on the level of income, it was determined that those who have a monthly income of $1000 €$ and more preferred cesarean section more than those with monthly income of $500 €$ or less. $(p=0.046)$

No correlation was found between the number of follow-ups in Family Health Centers during pregnancy and working status of mothers with the preferred delivery method. 
Table 1. Sociodemographic characteristics of participants

\begin{tabular}{|c|c|c|}
\hline Characteristics & $\mathbf{N}$ & $\%$ \\
\hline \multicolumn{3}{|l|}{ Maternal age (years) } \\
\hline$<20$ & 96 & 19.2 \\
\hline$\geq 20,<35$ & 254 & 50.8 \\
\hline$\geq 35$ & 150 & 30 \\
\hline \multicolumn{3}{|l|}{ Educational level } \\
\hline $\begin{array}{r}\text { Elementary or middle } \\
\text { school }\end{array}$ & 282 & 56.4 \\
\hline High school & 149 & 29.8 \\
\hline University & 69 & 13.8 \\
\hline \multicolumn{3}{|l|}{ Maternal tobacco use } \\
\hline Yes & 52 & 10.4 \\
\hline No & 448 & 89.6 \\
\hline \multicolumn{3}{|l|}{ Monthly Income } \\
\hline$<500 €$ & 241 & 48.2 \\
\hline $500-1000 €$ & 198 & 39.6 \\
\hline$>1000 €$ & 61 & 12.2 \\
\hline \multicolumn{3}{|l|}{ Mother working status } \\
\hline Yes & 104 & 20.8 \\
\hline No & 396 & 79.2 \\
\hline \multicolumn{3}{|l|}{$\begin{array}{l}\text { Number of antenatal follow- } \\
\text { up }\end{array}$} \\
\hline$<4$ & 59 & 11.8 \\
\hline$\geq 4$ & 441 & 88.2 \\
\hline
\end{tabular}

Table 2. Association between sociodemographic characteristics and delivery modes of mothers

\begin{tabular}{rccc}
\hline & \multicolumn{2}{c}{ Delivery mode } & \\
Characteristics & $\mathbf{N}(\%)$ & Vaginal & $\mathbf{p}$ \\
\hline Maternal age (years) & & & \\
$<20$ & $42(17.5 \%)$ & $44(16.9 \%)$ & \\
$\geq 20,<35$ & $126(52.5 \%)$ & $128(49.1 \%)$ & 0.651 \\
$\geq 35$ & $72(30 \%)$ & $78(30 \%)$ & \\
Educational level & & & \\
Elementary or & $136(56.7 \%)$ & $146(56.2 \%)$ & \\
middle* school & & & \\
High school & $64(26.7 \%)$ & $85(32.7 \%)$ & $\mathbf{0 . 0 2 1}{ }^{*}$ \\
University $^{*}$ & $40(16.6 \%)$ & $29(11.1 \%)$ &
\end{tabular}

Maternal tobacco use

\begin{tabular}{|c|c|c|c|}
\hline Yes & $24(10 \%)$ & $28(10.8 \%)$ & \multirow{2}{*}{0.234} \\
\hline No & $216(90 \%)$ & $232(89.2 \%)$ & \\
\hline \multicolumn{4}{|l|}{ Monthly Income } \\
\hline$<500 €^{*}$ & $116(48.3 \%)$ & $125(48.1 \%)$ & \multirow{3}{*}{0.046} \\
\hline $500-1000 €$ & $82(34.2 \%)$ & $116(44.6 \%)$ & \\
\hline$>1000 €^{*}$ & $42(17.5 \%)$ & $19(7.3 \%)$ & \\
\hline \multicolumn{4}{|l|}{ Mother working status } \\
\hline Yes & $56(23.3 \%)$ & $48(18.5 \%)$ & \multirow{2}{*}{0.891} \\
\hline No & $184(76.7 \%)$ & $212(81.5 \%)$ & \\
\hline \multicolumn{4}{|l|}{$\begin{array}{l}\text { Number of antenatal } \\
\text { follow-up }\end{array}$} \\
\hline$<4$ & $26(10.8 \%)$ & $33(12.7 \%)$ & \multirow{2}{*}{0.062} \\
\hline$\geq 4$ & $214(89.2 \%)$ & $227(87.3 \%)$ & \\
\hline
\end{tabular}

*p:statistically signifant groups

\section{Discussion}

In the research we conducted on delivery methods of the women living in Rize, we found that education level of mothers and income level of families are related to the preference of cesarean section.

Turkey has been the first ranking country in cesarean delivery rate by $54 \%$ in parallel with the increase around the world in recent years [2].

The recent increase in cesarean section rate in Turkey is noteworthy. Especially revealing the reasons of non-elective cesarean and determining the factors affecting expected mother's personal opinions constitute the main purpose of our research. Of the women who participated in the study, 240 $(48 \%)$ had delivery by cesarean section.

In a study conducted by Habiba et al. [7], the adaptation of mothers' demand with the gynecologists' eagerness to perform cesarean operation in the absence of medical indications was $15 \%$ in Spain, $19 \%$ in France, $22 \%$ in Holland, $75 \%$ in Germany and $79 \%$ in England. Cultural factors, legal responsibility and certain perinatal variables might play a role in this difference.

Cesarean birth rate increases with education and welfare level [8]. The ratio of cesarean section, which is $60 \%$ or more, with the highest education and welfare level is determined to be more than three times higher than the cesarean section with the lowest education and welfare level [9]. Epidemiological surveys in Brazil and Chile again have shown that cesarean rates are higher among women with higher levels of education, higher income categories, and private insurance status [10]. In another study conducted by Feng et al. [11], it was found that cesarean rate increased in women with high socioeconomic level. We also have determined in our study that women who are university or higher education graduates prefer cesarean delivery more than women who are primary school graduates, at significant degree. 
In the studies conducted, it was determined that the average age of women who performed first birth with cesarean was higher [12]. Cesarean births of pregnancies are more likely in women with pre-pregnancy disease history and health problems [13]. There is no correlation between gestational age and delivery method in our study. This can be explained by the sociodemographic attributes of the group included in the research.

Pregnant women who prefer cesarean section take the decision about delivery method in the second trimester in general [14]. This has proved that doctors who perform pregnancy follow-up need to talk about delivery method with their patients since the first follow-up and give the necessary information. Because women may have difficulty in deciding on the delivery method by media and other factors if they do not receive the first information from doctors. We did not find an association between antenatal follow-up numbers and delivery method preferences in our study. This can be explained by insufficient discussion on delivery method during antenatal follow-ups.

High CS ratios also impose an unnecessary financial burden on the health care system [15]. Strategies for preventing high CS rates become important when the high risks of intrapartum and postpartum complications are taken into account in mothers and infants. In many studies, it has been shown that delivery with elective cesarean section causes more morbidity and mortality to both mother and baby compared to vaginal delivery [16, 17].

In some studies conducted in Europe, there was a relationship between low education level and inadequate antenatal care [18]. Insufficient antenatal care might cause the increase of non-elective cesarean rates. In Turkey, easily accessible and free healthcare services have led this difference to be eliminated. In our study, 59 (11.8\%) of pregnant women had antenatal follow-up less than four times.

In a study conducted by Lund $\mathrm{K}$ et al. [19], smoking rate was found to increase with the increase of education levels of pregnant women. Smoking increases the risk of cesarean delivery by causing both prematurity and abortion delivery. Again the increase of unbalanced nutrition and obesity risks of pregnant women with high socioeconomic level might have increased elective cesarean risk [20,21]. We did not research the relation between education level and obesity in our study, however smoking rate of participants was $9.6 \%$ and no relation was found with delivery method and smoking.

One of the strengths of our study is that pregnant follow-ups were performed regularly by the same family physicians. Another powerful aspect is that all the data were taken face-to-face with the patients who participated in the study.

The weakness of our study may be that it is a mono-center study and elective cesarean situations that might affect delivery method are not investigated in detail.

\section{Conclusion}

In this study conducted in Turkey, which has the top ranking cesarean rates around the world, it has been indicated that there is a relation between high education level and high socioeconomic status with cesarean delivery preference. Informing expectant mothers properly by family physicians will help them to make right delivery method choice.

\section{Conflict of interest: none.}

Funding: none.

\section{References}

1. Ye J, Zhang J, Mikolajczyk R, Torloni MR, Gulmezoglu AM, Betran AP. Association between rates of caesarean section and maternal and neonatal mortality in the 21st century: a worldwide population-based ecological study with longitudinal data. BJOG 2015;123(5):745-753. doi: https://doi.org/10.1111/1471-0528.13592

2. WHO Statement on caesarean section rates. World Health Organization Human Reproduction Programme 10 April 2015. Reprod Health Matters 2015;23(45):149-150. Available from: doi: http://www.ncbi.nlm.nih.gov/pubmed/26278843

3. Al-Mufti R, McCarthy A, Fisk NM. Survey of obstetricians' personal preference and discretionary practice. Eur J Obstet Gynecol Reprod Biol 1997;73(1):1-4. doi: https://doi.org/10.1016/S0301-2115(96)02692-9

4. F. Gary Cunningham, John C. Hauth, Kenneth J. Leveno, Larry Gilstrap Iii, Steven L. Bloom, Katharine D. Wenstrom. Williams obstetrics. Williams Obstetrics 2010:1239-1326.

5. Park CS, Yeoum SG, Choi ES. Study of subjectivity in the perception of cesarean birth. Nurs Heal Sci 2005;7(1):3-8. doi: https://doi.org/10.1111/j.1442-2018.2005.00206.x

6. Donati S, Grandolfo M, Andreozzi S. Do Italian mothers prefer cesarean delivery? Birth 2003;30:89-93. doi: https://doi.org/10.1046/j.1523536X.2003.00226.x

7. Habiba M, Kaminski M, Da Frè M, Marsal K, Bleker O, Librero J, et al. Caesarean section on request: A comparison of obstetricians' attitudes in eight European countries. BJOG An Int J Obstet Gynaecol 2006;113(6):647-56. doi: https://doi.org/10.1111/j.1471-0528.2006.00933.x

8. Neuman, M., Alcock, G., Azad, K et al. Prevalence and determinants of caesarean section in private and public health facilities in underserved South Asian communities: cross-sectional analysis of data from Bangladesh, India and Nepal. BMJ Open 2014;4(12):e005982. doi: http://dx.doi.org/10.1136/bmjopen-2014-005982 
9. Koc I. Increased Cesarean section rates in Turkey. Eur J Contracept Reprod Heal Care 2003;8(1):1-10. doi: https://doi.org/10.1080/ejc.8.1.1.10

10. Behague DP, Victora CG, Barros FC. Consumer demand for caesarean sections in Brazil: informed decision making, patient choice, or social inequality? A population based birth cohort study linking ethnographic and epidemiological methods. BMJ 2002;324(7343):942-945. doi: https://doi.org/10.1136/bmj.324.7343.942

11. Feng L, Yue Y. Analysis on the 45-year cesarean rate and its social factors. Med Soc 2002;15:14-16.

12. Liu TC, Chen CS, Tsai YW, Lin HC. Taiwan's high rate of cesarean births: impacts of national health insurance and fetal gender preference. Birth 2007;34(2):115-122. doi: https://doi.org/10.1111/j.1523-536X.2007.00157.x

13. Roman H, Blondel B, Bréart G, Goffinet F. Do risk factors for elective cesarean section differ from those of cesarean section during labor in low risk pregnancies? J Perinatal Med 2008;36:297-305. doi: https://doi.org/10.1515/JPM.2008.044

14. Chu KH, Tai CJ, Hsu CS, et al. Women's preference for cesarean delivery and differences between Taiwanese women undergoing different modes of delivery. BMC Health Serv Res 2010;10:138. doi: https://doi.org/10.1186/1472-6963-10-138

15. Ronsmans C, Holtz S, Stanton C. Socioeconomic differentials in cesarean rates in developing countries: A retrospective analysis. Lancet 2006;368(9546):1516-1523. doi: https://doi.org/10.1016/S0140-6736(06)69639-6

16. Magann EF, Evans S, Hutchinson M, et al. Postpartum hemorrhage after cesarean delivery: an analysis of risk factors. South Med J 2005;98(7):681-685. doi: https://doi.org/10.1097/01.SMJ.0000163309.53317.B8

17. DiMatteo MR, Morton SC, Lepper HS, et al. Cesarean childbirth and psychosocial outcomes: A meta-analysis. Health Psychol 1996;15(4):303314. doi: https://doi.org/10.1037/0278-6133.15.4.303

18. Delvaux T, Buekens P, Godin I, Boutsen M. Barriers to prenatal care in Europe. Am J Prev Med 2001;21(1):52-59. doi: https://doi.org/10.1016/S0749-3797(01)00315-4

19. L und KE, Lund M. Røyking og sosial ulikhet i Norge [Smoking and social inequality in Norway] (in Norwegian with English abstract). Tidsskr Nor Laegeforen 2005; 125(5):5603.

20. England L, Zhang J. Smoking and risk of preeclampsia: a systematic review. Front Biosci 2007;12:2471-2483. doi: https://doi.org/10.2741/2248

21. Reddy UM, Branum AM, Klebanoff MA. Relationship of maternal body mass index and height to twinning. Obstet Gynecol 2005;105(3);593597. doi: https://doi.org/10.1097/01.AOG.0000153491.09525.dd 